\title{
$\frac{100}{\text { LAT }}$ RPEiS
}

\section{POLSKIE WYKAZY CZASOPISM NAUKOWYCH - PODSUMOWANIE DOTYCHCZASOWYCH DOŚWIADCZEŃ Z PERSPEKTYWY CZASOPISM PRAWNICZYCH}

\section{WPROWADZENIE}

Okragły jubileusz „Ruchu Prawniczego, Ekonomicznego i Socjologicznego” stanowi znakomita okazję do podsumowania stanu polskich czasopism prawniczych oraz podjęcia próby zdiagnozowania najważniejszych problemów, przed jakimi stoi obecnie polskie czasopiśmiennictwo prawnicze. Jednym z obszarów, który budzi aktualnie znaczne zainteresowanie, jest ocenianie czasopism naukowych za pomocą narzędzi bibliometrycznych. Od końca XX w. czasopisma naukowe sa poddawane ocenom parametrycznym dokonywanym przez organy zarządzające nauką polską i ich redakcje borykają się z szeregiem problemów, które te oceny generuja. Tworzenie rankingów czasopism naukowych jest szczególnie skomplikowane w przypadku czasopism interdyscyplinarnych, takich jakim jest Ruch. Niniejszy artykuł analizuje doświadczenia z wydawaniem urzędowego wykazu czasopism naukowych w Polsce, ze szczególnym uwzględnieniem czasopism prawniczych.

\section{DOTYCHCZASOWE PODSTAWY PRAWNE TWORZENIA WYKAZU CZASOPISM NAUKOWYCH}

W Polsce, podobnie jak w większości państw europejskich, nie powstał wyspecjalizowany ranking czasopism prawniczych ${ }^{1}$. Jest to istotna słabość środowiska badaczy prawa, gdyż nie mamy narzędzia, do którego moglibyśmy się

\footnotetext{
* Grzegorz Wierczyński, Uniwersytet Gdański, grzegorz.wierczynski@prawo.ug.edu.pl, https://orcid.org/0000-0001-9073-8831.

1 Więcej na ten temat zob. Wierczyński (2020): 3.
} 
odwołać przy dyskusjach nad tworzeniem ogólnej urzędowej listy czasopism naukowych. Lista taka zaczęła być sporządzana przez Komitet Badań Naukowych pod koniec lat dziewięćdziesiątych. Ustawa z 8 października 2004 r. o zasadach finansowania nauki ${ }^{2}$ przekazała jego zadania w zakresie finansowania ministrowi właściwemu dla spraw nauki i dlatego od 2005 r. wykazy czasopism naukowych są opracowywane przez Ministerstwo Nauki.

Pierwotnie wykazy czasopism nie były oparte na powszechnie obowiąującym akcie normatywnym. Stało się tak dopiero po wydaniu rozporządzenia Ministra Nauki i Szkolnictwa Wyższego z 13 lipca 2012 r. w sprawie kryteriów i trybu przyznawania kategorii naukowej jednostkom naukowym ${ }^{3}$. Rozporządzenie to traktowało wykaz czasopism naukowych jako narzędzie do ewaluacji jednostek naukowych. Zawarta w tym rozporządzeniu regulacja odnośnie do tworzenia wykazu czasopism naukowych była mocno niepełna. Dotyczący tego zagadnienia $\S 14$ stanowił, że „nie rzadziej niż raz w roku, Minister ogłasza, w formie komunikatu, w Biuletynie Informacji Publicznej na stronie podmiotowej ministra, wykaz czasopism naukowych wraz z liczba punktów przyznawanych za publikację w tych czasopismach" oraz że wykaz ten składa się z trzech części: A, B i C. Część A określała liczbę punktów za publikacje w czasopismach naukowych posiadających współczynnik wpływu impact factor (IF), znajdujących się w bazie Journal Citation Reports (JCR); część B określała liczbę punktów za publikacje w czasopismach naukowych nieposiadajacych współczynnika wpływu impact factor (IF), część C zaś określała liczbę punktów za publikacje w czasopismach naukowych znajdujących się w bazie European Reference Index for the Humanities (ERIH) ${ }^{4}$. Rozporządzenie nie określało jednak ani kryteriów, ani trybu oceny czasopism naukowych, nie określało nawet zakresu, w którym miały się mieścić punkty za publikacje w czasopismach naukowych przypisanych do poszczególnych części wykazu. Zamiast tej regulacji rozporządzenie zawierało subdelegację - w $\S 14$ ust. 1 rozporządzenia z 2012 r. Minister Nauki i Szkolnictwa Wyższego sam siebie upoważnił do wydania komunikatu regulującego omawiane kwestie ${ }^{5}$. Komunikat w tej sprawie został wydany w maju 2013 r. ${ }^{6}$ Zgodnie z tym komunikatem część B wykazu była tworzona na podstawie ankiet składanych przez zainteresowane redakcje (na aprobatę zasługuje to, że ankiety te były dostępne publicznie). W ankietach tych redakcje deklarowały spełnianie określonych kryteriów formalnych, a jedynym warunkiem przejścia do drugiego

2 T.jedn.: Dz. U. 2008, Nr 169, poz. 1049 ze zm.

${ }^{3}$ T.jedn.: Dz. U. 2014, poz. 1126 (dalej jako: rozporządzenie z 2012 r.).

${ }^{4}$ To ostatnie rozwiazanie było nowościa, gdyż wcześniej wykaz czasopism zawierał tylko odpowiedniki części A i B.

${ }^{5}$ Formuła ta naruszała zarówno art. 92 Konstytucji, jak i przepis upoważniający, na podstawie którego wydano powołane rozporządzenie, skoro bowiem Minister miał te zasady określić w drodze rozporządzenia, to jednocześnie oznacza, że nie miał ich określać w drodze komunikatu.

${ }^{6}$ Komunikat Ministra Nauki i Szkolnictwa Wyższego z 29 maja 2013 r. w sprawie kryteriów i trybu oceny czasopism naukowych, <http://www.bip.nauka.gov.pl/wykaz-czasopism-naukowych/ komunikat-ministra-nauki-i-szkolnictwa-wyzszego-z-dnia-29-maja-2013-r-w-sprawie-kryteriow-itrybu-oceny-czasopism-naukowych html> [dostęp: 29.01.2021]. 
etapu oceny było zadeklarowanie przez redakcję, że dane czasopismo ma charakter naukowy.

Rozporządzenie z 2012 r. sankcjonowało również istniejącą wcześniej praktykę, która sprowadzała się do tego, że ministerialne wykazy czasopism działały z wsteczną mocą obowiązująca. Zgodnie z § 14 ust. 4 powołanego rozporządzenia „za publikację w czasopiśmie naukowym przyznaje się liczbę punktów określoną w wykazie czasopism naukowych obowiązującym na koniec roku kalendarzowego, w którym ukazała się publikacja”. Ponieważ wykazy najczęściej ukazywały się właśnie pod koniec roku, oznaczało to, że naukowcy dopiero po opublikowaniu danego artykułu dowiadywali się, jak będzie on oceniony w procesie ewaluacji naukowej. Zagadnienie to nie może pozostać bez krytycznej wzmianki - przyjmowanie, że wykaz działa wstecz, jest w sposób oczywisty niezgodne ze współczesnymi standardami praworządności ${ }^{7}$, nie da się zarazem przekonująco wskazać innej zasady czy wartości konstytucyjnej, która usprawiedliwiałaby odstapienie od ogólnego zakazu retroakcji w omawianym przypadku.

Omówiony powyżej model regulacji został następnie powtórzony w rozporządzeniu Ministra Nauki i Szkolnictwa Wyższego z 27 października 2015 r. w sprawie kryteriów i trybu przyznawania kategorii naukowej jednostkom naukowym ${ }^{8}$. W tym rozporządzeniu część zasad odnoszących się do kryteriów oraz trybu oceny czasopism naukowych zawartych wcześniej w komunikacie ministra zostało rozbudowanych i przeniesionych do załącznika do rozporządzenia, ale część kwestii wciąż była regulowana w komunikacie ministra (np. kwestia baz uwzględnianych w ocenie czasopism). Rozporządzenie to nie odegrało jednak znaczącej roli, gdyż utraciło moc w tym samym momencie, w którym wchodziło w życie, a w rozporządzeniu Ministra Nauki i Szkolnictwa Wyższego z 12 grudnia 2016 r. w sprawie przyznawania kategorii naukowej jednostkom naukowym i uczelniom, w których zgodnie z ich statutami nie wyodrębniono podstawowych jednostek organizacyjnych ${ }^{9}$, postanowiono, że do ewaluacji jednostek naukowych za lata 2013-2016 zastosowano zbiorczy wykaz czasopism naukowych utworzony przez ujednolicenie wykazów ogłoszonych w tych latach przez ministra zgodnie z $§ 14$ ust. 2 rozporządzenia z 2012 r. $^{10}$

Zasadnicze zmiany przyniosła ustawa z 20 lipca 2018 r. - Prawo o szkolnictwie wyższym i nauce ${ }^{11}$. Po raz pierwszy w samej ustawie pojawiły się przepisy odnoszące się do tworzenia wykazu czasopism naukowych zawierającego punktację tych czasopism. Zgodnie z art. 265 ust. 9 pkt 2 powołanej

${ }^{7}$ Zob. chociażby Pietrzykowski (2004): 195-250.

${ }^{8}$ Dz. U. poz. 2015.

${ }^{9}$ Dz. U. poz. 2154.

${ }^{10}$ Zob. komunikat Ministra Nauki i Szkolnictwa Wyższego z 25 stycznia 2017 r. w sprawie wykazu czasopism naukowych wraz z liczbą punktów przyznanych za publikacje naukowe w tych czasopismach, ustalonego na podstawie wykazów ogłoszonych w latach 2013-2016, <https:// www.bip.nauka.gov.pl/wykaz-czasopism-naukowych/komunikat-w-sprawie-wykazu-czasopismnaukowych-wraz-z-liczba-punktow-przyznanych-za-publikacje-naukowe-w-tych-czasopismachustalony-na-podstawie-wykazow-ogloszonych-w-latach-2013-2016.html> [dostęp: 29.01.2021].

11 T.jedn.: Dz. U. 2020, poz. 85 ze zm. 
ustawy ewaluacja jednostek naukowych obejmuje artykuły naukowe opublikowane w „czasopiśmie naukowym publikujacym recenzowane artykuły [...], ujętych w międzynarodowych bazach czasopism naukowych o największym zasięgu” lub w „czasopiśmie naukowym będącym przedmiotem projektów finansowanych w ramach programu »Wsparcie dla czasopism naukowych «". Już na poziomie ustawy przesądzono zatem, że w wykazie czasopism naukowych uwzględnione zostaną tylko czasopisma indeksowane w międzynarodowych bazach czasopism naukowych (i to tylko tych „o największym zasięgu”), a jedyny wyjątek został przewidziany dla czasopism, które zakwalifikowały się do programu „Wsparcie dla czasopism naukowych”. Oznaczało to, że warunki zakwalifikowania się do tego programu stały się warunkami umieszczenia w wykazie tych czasopism, które w chwili jego sporządzania nie były indeksowane w międzynarodowych bazach czasopism naukowych.

Artykuł 265 ust. 10 Prawa o szkolnictwie wyższym stanowi, że „wydawnictwom, czasopismom i materiałom z konferencji, o których mowa w ust. 9, przypisuje się punkty będące miarą ich renomy”, oraz że „czasopismom i materiałom z konferencji przypisuje się dyscypliny naukowe” (problemy, jakie generuje to postanowienie, zostaną omówione w dalszej części artykułu).

Zgodnie z art. 267 ust. 2 pkt 2 lit. b Prawa o szkolnictwie wyższym sposób sporządzania wykazów czasopism naukowych i recenzowanych materiałów z konferencji międzynarodowych, o których mowa w art. 265 ust. 9 pkt 2, oraz sposób ustalania i przypisywania im liczby punktów, określa w drodze rozporządzenia minister właściwy do spraw szkolnictwa wyższego i nauki, „mając na uwadze uznaną renomę czasopism i materiałów z konferencji”. Na podstawie powołanego przepisu zostało wydane rozporządzenie Ministra Nauki i Szkolnictwa Wyższego z 7 listopada 2018 r. w sprawie sporządzania wykazów wydawnictw monografii naukowych oraz czasopism naukowych i recenzowanych materiałów z konferencji międzynarodowych ${ }^{12}$. Zgodnie z $§ 6$ tego rozporządzenia wykaz czasopism miał objacc wyłącznie:

1) czasopisma indeksowane $w$ jednej $z$ pięciu wskazanych międzynarodowych baz danych (Scopus oraz 4 bazy należące do Web of Science: Science Citation Index Expanded, Social Sciences Citation Index, Arts \& Humanities Citation Index, Emerging Sources Citation Index),

2) czasopisma naukowe zakwalifikowane do ministerialnego programu „Wsparcie dla czasopism naukowych”,

3) „zagraniczne czasopisma naukowe ujęte w międzynarodowej bazie European Reference Index for the Humanities and Social Sciences (ERIH+) oraz nieujęte w bazach, o których mowa w ust. 1 pkt 1 , jeżeli jest to uzasadnione pozycją tych czasopism".

Z jednej strony rozporządzenie z 2018 r. zasadniczo zawężało pojęcie „międzynarodowych baz czasopism naukowych o największym zasięgu”, za bazy takie uznając wyłącznie bazy należące do grupy baz Web of Science, bazę Scopus oraz bazę ERIH+. Z drugiej strony rozporządzenie wykraczało poza upoważnienie ustawowe, gdyż art. 265 ust. 9 pkt 2 Prawa o szkolnictwie wyższym

12 T.jedn.: Dz. U. 2020, poz. 349 (dalej jako: rozporządzenie z 2018 r.). 
i nauce nie przewiduje uwzględniania w ewaluacji artykułów opublikowanych $\mathrm{w}$ czasopismach nieujętych w międzynarodowych bazach (z wyjątkiem tych zakwalifikowanych do ministerialnego programu „W sparcie dla czasopism naukowych").

Skala punktacji znacząco odbiega od wcześniejszych skal - przyjęto 6 poziomów punktacji: 20, 40, 70, 100, 140 i 200. W pierwszym, bibliometrycznym etapie oceny czasopisma, o których mowa w punkcie 1 , mogły zyskać do 200 pkt (zależało to od indeksów cytowań w tych bazach), natomiast czasopisma, o których mowa w punkcie 2 i 3, uzyskiwały minimalną liczbę (20) punktów. W drugim etapie zespoły ekspertów z poszczególnych dyscyplin naukowych mogły zmienić ocenę wynikająca z pierwszego etapu o maksymalnie dwa poziomy. Przeprowadzenie obu tych etapów prac zostało powierzone Komisji Ewaluacji Nauki.

$\mathrm{Na}$ podstawie tak ustalonych zasad sporządzono wykaz czasopism naukowych i recenzowanych materiałów z konferencji międzynarodowych, który został opublikowany jako załacznik do komunikatu MNiSW z 31 lipca 2019 r. ${ }^{13}$ Spośród wydawanych w Polsce naukowych czasopism prawniczych tylko dwa były indeksowane w bazach, o których mowa w punkcie 1: „Journal of Juristic Papyrology” oraz „Polish Yearbook of International Law”. Dla pozostałych polskich czasopism prawniczych jedyną realnie dostępną droga do wykazu było zakwalifikowanie się do ministerialnego programu „Wsparcie dla czasopism naukowych”. Jednym z takich czasopism był „Ruch Prawniczy, Ekonomiczny i Socjologiczny". Wiele innych prestiżowych polskich czasopism prawniczych nie zakwalifikowało się do wspomnianego programu, gdyż byłon skierowany wyłącznie do czasopism wydawanych w otwartym dostępie (nie później niż w terminie 6 miesięcy od dnia wydania danego numeru) ${ }^{14}$. W wyniku wieloletniego braku wsparcia publicznego wiele polskich czasopism prawniczych ukazuje się wyłacznie dzięki wpływom z prenumeraty, a wsparcie finansowe możliwe do uzyskania w powołanym programie było zbyt niskie, żeby zrównoważyć rezygnację z tych wpływów. Pozostałe kryteria, od których zależało zakwalifikowanie czasopisma do powołanego programu, miały charakter formalny i w efekcie tą drogą do wykazu czasopism naukowych trafiły nie tylko czasopisma o powszechnie uznanej pozycji, ale również takie, które takiej pozycji nie maja. $\mathrm{Z}$ jednej strony w wykazie zabrakło wielu uznanych czasopism prawniczych, a z drugiej - znalazły się w nim czasopisma, które nie cieszą się powszechnym uznaniem. Sytuacji nie zmienił drugi etap procedury - zespół doradczy do spraw czasopism przypisanych do dyscypliny nauki prawne podwyższył ocenę kilku czasopismom z 20 do 40 pkt, ale kryteria tego podwyższenia nie zostały ujawnione, a wyniki tej oceny są całkowicie niejasne. Taką samą liczbę punk-

${ }^{13}$ Wykaz został ogłoszony na:<http://www.bip.nauka.gov.pl/akty-prawne-mnisw/komunikatministra-nauki-i-szkolnictwa-wyzszego-z-dnia-31-lipca-2019-r-w-sprawie-wykazu-czasopismnaukowych-i-recenzowanych-materialow-z-konferencji-miedzynarodowych-wraz-z-przypisanaliczba-punktow.html> [dostęp: 5.02.2021].

14 Zob. § 4 ust. 1 pkt 2 rozporządzenia Ministra Nauki i Szkolnictwa Wyższego z 20 września 2018 r. w sprawie pomocy de minimis w ramach programu „Wsparcie dla czasopism naukowych”, Dz. U. poz. 1832. 
tów, jak „Ruch Prawniczy, Ekonomiczny i Socjologiczny” (40) uzyskało kilka czasopism prawniczych, których prestiż w środowisku polskich badaczy prawa oraz współczynniki cytowań są znacznie niższe.

Na początku grudnia 2019 r. weszło w życie rozporządzenie Ministra Nauki i Szkolnictwa Wyższego z 28 listopada 2019 r. zmieniające rozporządzenie w sprawie sporządzania wykazów wydawnictw monografii naukowych oraz czasopism naukowych i recenzowanych materiałów z konferencji międzynarodowych ${ }^{15}$. Rozporządzenie to zmieniło $§ 6$ rozporządzenia z $2018 \mathrm{r}$. w ten sposób, że usunęło wymaganie, by czasopisma, które były dodawane na zasadzie wyjątku (zob. punkt 3 powyżej), były wyłącznie zagraniczne. Dzięki temu również polskie czasopisma mogły występować o wpisanie do wykazu na tej podstawie, że sa indeksowane bazie European Reference Index for the Humanities and Social Sciences (ERIH+). Jednocześnie umożliwiono Ministrowi Nauki i Szkolnictwa Wyższego sporządzenie wykazu czasopism według uproszczonej procedury, z pominięciem etapu oceny eksperckiej. Na podstawie tak zmienionych kryteriów i w tak uproszczonej procedurze opracowano nowy wykaz, który ogłoszono w formie załącznika do komunikatu MNiSW z 18 grudnia 2019 r. ${ }^{16} \mathrm{~W}$ efekcie do wykazu dopisano pokaźną liczbę czasopism prawniczych, ale z minimalna liczbą punktów. W omawianym stanie prawnym baza ERIH+ oraz program „Wsparcie dla czasopism naukowych” (WCN) przejęły funkcję dotychczasowej listy B. W porównaniu z poprzednim stanem prawnym należy odnotować pewien regres w kwestii jawności procesu tworzenia tej części wykazu - jawne ankiety redakcji czasopism zostały zastapione przez wnioski składane do bazy ERIH+ oraz wnioski składane w ramach programu WCN, a w obu tych przypadkach wnioski te nie sa powszechnie dostępne.

Żeby zrozumieć to, co się wydarzyło z ministerialnym wykazem czasopism naukowych na początku 2021 r., trzeba wyjaśnić, że znaczenie tego wykazu znacznie wzrosło wraz z wejściem w życie Prawa o szkolnictwie wyższym i nauce. Ustawa ta powiązała uprawnienia jednostek naukowych do nadawania stopni naukowych (doktora i doktora habilitowanego) z posiadaniem przez nie odpowiedniej kategorii naukowej. Zgodnie z art. 185 ust. 1 oraz art. 218 ust. 1 uprawnienia te mają wyłącznie te uczelnie i instytuty, które w danej dyscyplinie posiadaja kategorię naukowa $\mathrm{A}+, \mathrm{A}$ lub $\mathrm{B}+. \mathrm{W}$ procesie ewaluacji jednostek naukowych zasadnicze znaczenie ma ocena dorobku naukowego, a ocena ta odbywa się za pomocą dwóch narzędzi - wykazu czasopism naukowych oraz wykazu wydawnictw naukowych. Inną istotna zmianą było wprowadzenie zasady, że ewaluacja jednostek naukowych obejmuje osiagnięcia wszystkich pracowników naukowych i naukowo-badawczych przypisanych do danej dyscypliny naukowej zatrudnionych w danej jednostce (art. 265 ust. 2 Prawa o szkolnictwie wyższym i nauce). Trzecią istotną zmianą była znacząca deprecjacja rozdziałów w monografiach naukowych. Wszystkie te zmiany

15 Dz. U. poz. 2341

16 Wykaz został ogłoszony na: <http://www.bip.nauka.gov.pl/inne2/komunikat-ministra-naukii-szkolnictwa-wyzszego-z-dnia-18-grudnia-2019-r-w-sprawie-wykazu-czasopism-naukowych-irecenzowanych-materialow-z-konferencji-miedzynarodowych.html> [dostęp: 5.02.2021]. 
spowodowały, że w porównaniu z poprzednim stanem prawnym znaczenie wykazu czasopism znacząco wzrosło. Pierwsza ewaluacja jednostek naukowych na podstawie tak zmienionych zasad ma się odbyć w 2022 r. i objać lata 20172021. Ewaluacja ta odbędzie się na podstawie ostatniego wykazu czasopism ogłoszonego przez Ministra Edukacji i Nauki.

Minister Edukacji i Nauki 9 lutego 2021 r. wydał komunikat w sprawie wykazu czasopism naukowych i recenzowanych materiałów z konferencji ${ }^{17}$. Już dwa dni później Komisja Ewaluacji Nauki wydała oświadczenie w sprawie tego wykazu ${ }^{18}$. Komisja poinformowała w nim, że „została zaskoczona publikacją wykazu czasopism naukowych”, gdyż zawiera on „pozycje, których Komisja nie procedowała i nie rekomendowała”. Komisja oświadczyła, że przygotowała projekt tego wykazu, uwzględniając czasopisma, które zostały ujęte we wskazanych w rozporządzeniu międzynarodowych bazach danych, ale w wersji opublikowanej przez Ministra „znalazły się 73 czasopisma, które nie były procedowane ani rekomendowane przez KEN”, a „w przypadku 237 czasopism pojawiła się podwyższona punktacja, która również nie była konsultowana z KEN”. Komisja podkreśliła, że „w żadnym dostępnym źródle nie znalazła merytorycznego uzasadnienia wprowadzonych zmian”. O skali nadużyć świadczy chociażby to, że niektórym czasopismom nieindeksowanym w bazach Web of Science i Scopus podniesiono punktację do 100 pkt, co było sprzeczne z merytorycznymi zasadami przewidzianymi w rozporządzeniu z $2018 \mathrm{r}$.

Wiele spośród tych czasopism, które zostały wpisane na listę lub którym podwyższono punktację bez wymaganego trybu oraz wbrew obowiązujacym zasadom merytorycznym, to czasopisma prawnicze. Dlatego jednym z pierwszych gremiów, które zareagowały na opisane zdarzenia, był Komitet Nauk Prawnych Polskiej Akademii Nauk. W uchwale nr 1/2021 z 15 lutego 2021 r. ${ }^{19}$ Komitet zdecydowanie zaprotestował „tak w sprawie sposobu opracowywania powołanego wykazu, jak i jego zawartości”. Komitet podkreślił, że „władczy akt ministra nie może być działaniem arbitralnym, sprzecznym z prawem”, i ocenił, że czasopisma, o których mowa w oświadczeniu Komisji Ewaluacji Nauki: „zostały dodane do wskazanego wykazu, bądź wartość punktowa czasopism została podniesiona, w sposób nietransparentny, z myślą o dowartościowaniu pewnych środowisk, a przede wszystkim wbrew zasadom ustalania punktacji wynikającym z powołanego rozporządzenia”.

17 Komunikat został ogłoszony na: <https://www.gov.pl/web/edukacja-i-nauka/nowy-rozrozszerzony-wykaz-czasopism-naukowych-i-recenzowanych-materialow-z-konferencji-miedzynarodowych> [dostęp: 22.02.2021].

18 Oświadczenie KEN z 11 lutego 2021 r. zostało ogłoszone na: <https://forumakademickie.pl/ sprawy-nauki/komunikat-komisji-ewaluacji-nauki/> [dostęp: 22.02.2021].

19 Uchwała została ogłoszona na: <http://www.knp.pan.pl/index.php?option=com_content \&view=article\&id=216:uchwala-nr-01-2021-komitetu-nauk-prawnych-polskiej-akademii-naukz-dnia-15-lutego-2021-roku-dot-wykazu-i-punktacji-czasopism-naukowych-i-recenzowanychmaterialow-z-konferencji-miedzynarodowych\&catid=69\&Itemid=167> [dostęp: 22.02.2021]. 
W tym samym dniu zaprotestował też Komitet Psychologii PAN ${ }^{20}$. Podkreślił, że „tryb powstania wykazu - z pominięciem Komisji Ewaluacji Nauki - stanowi poważne naruszenie Ustawy z 20 lipca 2018 r. Prawo o Szkolnictwie Wyższym i Nauce oraz Rozporządzenia MNiSW z dnia 7 listopada 2018 r. [...]”, ,aktualizowanie punktacji wybranych czasopism nie opiera się na obiektywnych kryteriach i jest nietransparentne, podczas gdy dotychczasowa punktacja, opracowana przez Komisję Ewaluacji Nauki i konsultowana z ekspertami ze wszystkich dziedzin nauki, wynikała z wiarygodnych wskaźników bibliometrycznych”, „podwyższenie punktacji polskojęzycznych czasopism regionalnych, o krótkiej historii i niskiej renomie, będzie motywowało wielu pracowników nauki do publikacji wyników badań poza obiegiem nauki światowej”, „w ten sposób nie buduje się prestiżu nauki polskiej, natomiast powoduje jej marginalizację”, „umieszczenie w wykazie periodyków stricte publicystycznych, które nie posiadają odpowiednich procedur niezależnych recenzji, rozmywa ważne rozróżnienie pomiędzy piśmiennictwem naukowym a publicystyka”, co „prowadzi do upadku autorytetu nauki i utraty jej unikalnego statusu”, a także, że „podwyższanie punktacji szeregu czasopism związanych z określonymi ośrodkami naukowymi oraz wybranymi dyscyplinami prowadzi do konfliktowania środowiska naukowego i stawia w dwuznacznej sytuacji niektóre redakcje oraz uczelnie".

Równie zdecydowane stanowisko zajął Komitet Etyki w Nauce Polskiej Akademii Nauk. W stanowisku nr 2/2021 z 16 lutego 2021 r. ${ }^{21}$ Komitet ten uznał między innymi, że sposób wprowadzenia zmian do wykazu był nie tylko niezgodny z prawem, ale był też „bezprecedensowym pogwałceniem etycznych zasad bezstronnej i sprawiedliwej oceny, które będzie skutkować spadkiem zaufania do nauki, obniżeniem poziomu badań naukowych w kraju, a także niekorzystnym postrzeganiem polskiej nauki na arenie międzynarodowej”. Komitet zwrócił też uwagę między innymi na to, że „arbitralne zmiany w wykazie przekreślają wysiłki tysięcy polskich badaczek i badaczy mające na celu uzyskiwanie jak najlepszych wyników, sugerując, że o ich karierze naukowej decydują nie rzeczywiste osiagnięcia naukowe, lecz spełnianie motywowanych światopoglądowo oczekiwań rządzących”. Komitet ocenił, że tryb wprowadzania zmian w wykazie „podważa reputację ośrodków wydających czasopisma, które bez merytorycznego uzasadnienia dodano do wykazu lub których punktacja została w ten sposób podniesiona”, „może być podstawą do kwestionowania lub zaskarżania wyników ewaluacji jednostek naukowych, która stanowi m.in. podstawę podziału środków przeznaczonych na finansowanie nauki" oraz „pozostaje w sprzeczności z zasadami równego traktowania i szacunku dla ludzi nauki”.

${ }^{20}$ Stanowisko opublikowano na: <http://www.kompsych.pan.pl/images/Uchwa\%C5\%82y/ Stanowisko_KP_PAN_ws_zmiany_punktacji_czasopism_naukowych.pdf> [dostęp: 27.02.2021].

21 Stanowisko została ogłoszone na: <http://www.ken.pan.pl/images/KEN_stanowisko_2_2021. pdf> [dostęp: 22.02.2021]. 
18 lutego zaprotestowała Akademia Młodych Uczonych PAN ${ }^{22}$. Młodzi naukowcy stwierdzili między innymi, że „ta uznaniowa ingerencja jest [...] wyrazem lekceważenia wyników pracy kilkudziesięciu zespołów ekspertów, które wypracowały obowiąujacy dotychczas wykaz, rekomendacji Komisji Ewaluacji Nauki, a także głosu wielu instytucji akademickich i naukowców, których działalność bezpośrednio zależy od przejrzystości i stabilności kryteriów oceny. Podważa ona zaufanie do procesu ewaluacji, na którym opiera się polityka jakości i finansowania badań, co może mieć w niedalekiej przyszłości fatalne konsekwencje. Tryb, w jakim wprowadzono zmiany, budzi również zastrzeżenia prawne. Dokonane w wykazie modyfikacje nie odzwierciedlają w większości przypadków poziomu naukowego czy znaczenia czasopism, zacierają natomiast granicę pomiędzy pismami znakomitymi a miernymi, a także promuja publicystykę kosztem prac naukowych”.

Mimo tak zdecydowanych reakcji ze strony środowiska akademickiego, Minister Edukacji i Nauki wydał kolejny komunikat 18 lutego 2021 r. „o zmianie i sprostowaniu” komunikatu z 9 lutego ${ }^{23}$, w którym dodał do wykazu 5 nowych czasopism naukowych oraz zwiększył liczbę punktów 96 czasopismom naukowym. Komisja Ewaluacji Nauki 22 lutego 2021 r. opublikowała komunikat, w którym oświadczyła, że „nie uczestniczyła w opracowaniu” zmian wprowadzonych powołanym komunikatem z 18 lutego 2021 r. ${ }^{24} \mathrm{~W}$ efekcie do wymienionych powyżej komitetów naukowych PAN wyrażających sprzeciw wobec sposobu utworzenia wykazu czasopism dołączyły m.in.: Konferencja Rektorów Akademickich Szkół Polskich ${ }^{25}$, Komitet Nauk Filozoficznych PAN ${ }^{26}$, Komitet Nauk o Kulturze PAN ${ }^{27}$, Komitet Nauk Demograficznych PAN ${ }^{28}$, Komitet Nauk o Literaturze PAN ${ }^{29}$, Komitet Nauk Politycznych PAN ${ }^{30}$, Komitet Nauk

22 Stanowisko opublikowano na: <https://amu.pan.pl/amu-pan-sprzeciwia-sie-arbitralnymzmianom-w-wykazie-czasopism> [dostęp: 27.02.2021].

${ }^{23}$ Komunikat został ogłoszony na: <https://www.gov.pl/web/edukacja-i-nauka/zmianai-sprostowanie-komunikatu-ministra-edukacji-i-nauki-z-dnia-9-lutego-2021-r-w-sprawiewykazu-czasopism-naukowych-i-recenzowanych-materialow-z-konferencji-miedzynarodowych> [dostęp: 22.02.2021].

${ }^{24}$ Komunikat nr 2/2021 KEN z 22 lutego 2021 r. został ogłoszony na:<https://forumakademickie. pl/sprawy-nauki/komunikat-komisji-ewaluacji-nauki> [dostęp: 27.02.2021].

25 Stanowisko Prezydium KRASP z 22 lutego 2021 r., opublikowane na: <https://www.krasp. org.pl/resources/upload/dokumenty/Uchwa\%C5\%82y/kadencja\%202020-2024/dok_9VIII-wykaz_ czasopism_naukowych.pdf> [dostęp: 12.03.2021].

${ }^{26}$ Sprzeciw opublikowano na: <https://knf.pan.pl/> [dostęp: 27.02.2021].

27 Poparcie opublikowane na: <http://www.knok.pan.pl/index.php/apele-i-stanowiska> [dostęp: 12.03.2021].

28 Uchwała nr 2/2021 Komitetu Nauk Demograficznych PAN z 22 lutego 2021 r., opublikowana na: <http://knd.pan.pl/images/Uchwa\%C5\%82a_2_2021.pdf> [dostęp: 12.03.2021].

29 Stanowisko Komitetu Nauk o Literaturze PAN z 23 lutego 2021 r., opublikowane na: <http://www.knp.pan.pl/index.php?option=com_content\&view=article\&id=219: stanowisko-nauko-literaturze-pan-z-23-02-2021-r-dla-uchwaly-komitetu-nauk-prawnych-w-sprawie-wykazu-ipunktacji-czasopism-naukowych\&catid=67\&Itemid=164> [dostęp: 19.03.2021].

30 Stanowisko Komitetu Nauk Politycznych PAN z 23 lutego 2021 r., <http://www.knpol.pan. pl/images/KNP_News/Stanowisko_nr_1-II-2021.pdf> [dostęp: 12.03.2021]. 
Orientalistycznych PAN ${ }^{31}$, Rada Główna Nauki i Szkolnictwa Wyższego ${ }^{32}$, Komitet Językoznawstwa $\mathrm{PAN}^{33}$, Komitet Socjologii PAN ${ }^{34}$, Komitet Słowianoznawstwa PAN ${ }^{35}$, Prezydium Komitetu Nauk Historycznych PAN ${ }^{36}$ i Komitet Nauk Pedagogicznych PAN ${ }^{37}$.

Zmiany wykazu czasopism naukowych wprowadzone w lutym $2021 \mathrm{r}$. przez Ministra Edukacji i Nauki, które nie wynikały z przewidzianej przez rozporządzenie z 2018 r. uchwały Komisji Ewaluacji Nauki, zostały dokonane $\mathrm{z}$ istotnym naruszeniem obowiązujacego prawa. Minister jest w omawianej procedurze organem władzy publicznej, a zatem - zgodnie z wyrażoną w art. 7 Konstytucji RP zasadą legalizmu - może działać wyłącznie na podstawie i w granicach prawa. W świetle obowiąujących przepisów uchwała Komisji Ewaluacji Nauki zawierajacca projekt wykazu czasopism wraz z ich punktacją jest koniecznym proceduralnym warunkiem wydania przez ministra samego wykazu ${ }^{38}$. W tym zakresie, w jakim minister wydał wykaz czasopism z pominięciem tej uchwały (niezależnie od tego, czy pominięcie to polegało na dopisaniu czasopisma czy na zmianie mu punktacji), wykroczył poza granice obowiąujaccego prawa.

W obecnym stanie faktycznym trudno liczyć na prawidłową reakcję karna na to działanie, gdyż prokuratura została podporządkowana rządowi i postępowania w sprawach urzędujacych ministrów albo nie są wszczynane, albo są umarzane. Jeśli zaś chodzi o reakcję w postaci skargi do sądu administracyjnego, to należy wspomnieć, że w wyroku z 10 grudnia 2020 r. Wojewódzki Sąd Administracyjny w Warszawie uznał, że „wykaz wydawnictw jest aktem (czynnościa) odnoszącą się wyłącznie do relacji zachodzaccych pomiędzy ocenianym (podlegajacym ewaluacji) podmiotem naukowym lub naukowo-dydak-

31 Poparcie dla uchwały KNP PAN z 23 lutego 2021 r., opublikowane na: <http://kno.pan.pl/ images/Poparcie_KNO_dla_Uchwa\%C5\%82y_KNP_PAN.pdf> [dostęp: 12.03.2021].

32 Stanowisko Nr 30/2021 Rady Głównej Nauki i Szkolnictwa Wyższego z 26 lutego 2021 r., opublikowane na:<http://www.rgnisw.nauka.gov.pl/stanowiska/stanowisko-nr-30-2021-rady-glownejnauki-i-szkolnictwa-wyzszego-z-dnia-26-lutego-2021-r-w-sprawie-najnowszego-wykazu-czasopism. html> [dostęp: 12.03.2021].

${ }^{33}$ Uchwała nr 2/2021 Komitetu Językoznawstwa PAN z 1 marca 2021 r., niepublikowana.

${ }_{34}$ Stanowisko Komitetu Socjologii PAN z 1 marca 2021 r., opublikowane na: http://www.knp. pan.pl/images/Stanowsko_Komitetu_Socjologii_PAN_w_sprawie_listy_czasopism.png> [dostęp: 12.03.2021].

${ }^{35}$ Uchwała nr 1/2021 Komitetu Słowianoznawstwa PAN z 4 marca 2021 r., ogłoszona na: http://komslow.pan.pl/images/Uchwala_nr_1_2021.pdf> [dostęp: 12.03.2021].

${ }^{36}$ Uchwała nr 1/2021 Prezydium Komitetu Nauk Historycznych PAN z 11 marca 2021 r., opublikowana na: <http://www.knp.pan.pl/images/KNH_Uchwaa_Prezydium_nr_1-2021.png> [dostęp: 19.03.2021].

${ }^{37}$ Stanowisko Komitetu Nauk Pedagogicznych PAN opublikowane na: <http://www. knped.pan.pl/index.php?option=com_content\&view=article\&id=397:stanowisko-komitetunauk-pedagogicznych-pan-w-sprawie-publikacji-przez-ministerstwo-edukacji-i-nauki-nowegorozszerzonego-wykazu-czasopism-naukowych-i-recenzowanych-materialow-z-konferencjimiedzynarodowych-opublikowanego-w-dniu-19-lutego-2021-roku\&catid=47\&Itemid=182> [dostęp: 16.03.2021].

${ }^{38} \mathrm{~W}$ postanowieniu z 4 grudnia 2019 r. WSA w Warszawie wyraził taki sam pogląd w odniesieniu do uchwał KEN w sprawie proponowanych kategorii naukowych (II SAB/Wa 575/19, Lex nr 2778006), a procedura w tych sprawach jest taka sama. 
tycznym i ministrem do spraw nauki i szkolnictwa wyższego”, „nie dotyczy natomiast w jakikolwiek sposób sytuacji prawnej wydawnictwa umieszczonego lub nieumieszczonego w wykazie". Na tej podstawie WSA uznał, że wykaz wydawnictw nie może być zaskarżony do sądu administracyjnego przez zainteresowane wydawnictwa ${ }^{39}$. Status prawny wykazu czasopism jest taki sam jak wykazu wydawnictw, należy więc przyjać, że również w tej sprawie WSA w Warszawie orzekłby podobnie. Oznacza to, że możliwość zaskarżenia do sądu administracyjnego pojawi się dopiero w momencie wydania decyzji w sprawie przyznania kategorii naukowej i będą ją miały wyłącznie jednostki naukowe (a nie - wydawcy czasopism). Kwestia legalności ustanowienia wykazu czasopism będzie jedynie pośrednio przedmiotem tego postępowania, którego głównym przedmiotem będzie legalność wydania decyzji w sprawie przyznania kategorii naukowej ${ }^{40}$.

Omawiana sytuacja unaoczniła istotne błędy dotychczasowej procedury tworzenia wykazu czasopism naukowych. Już wcześniej można było podnosić wątpliwość, czy wykaz ten powinno tworzyć ministerstwo w trybie właściwym dla wydawania aktów wewnętrznie obowiązujących. Ministerstwo nie jest bowiem organem, któremu wydawcy tych czasopism podlegaja w takim sensie, który uzasadniałby regulowanie ich działalności aktem wewnętrznie obowiąujaccym. Teraz jasne się stało, że powierzenie tego zadania ministerstwu nie daje gwarancji, że prace zostaną przeprowadzone w sposób legalny, transparentny i niezależny od nacisków ze strony zainteresowanych podmiotów. Dlatego poprawnym rozwiązaniem byłoby powierzenie tego zadania wyspecjalizowanej agencji państwowej niezależnej od władz politycznych, której działalność opierałaby się na powszechnie obowiązujących aktach prawnych, byłaby objęta prawem do informacji publicznej. W zakresie merytorycznej oceny czasopism podmiot taki powinien współpracować z komitetami naukowymi Polskiej Akademii Nauk, ponieważ są one „samorządną reprezentacja dyscypliny lub pokrewnych dyscyplin naukowych służącą integrowaniu uczonych z całego kraju" (art. 33 ustawy z 30 kwietnia 2010 r. o Polskiej Akademii Nauk ${ }^{41}$ ), a do ich ustawowych kompetencji należy między innymi „ocena wydawnictw naukowych" (art. 36 ust. 1 pkt 9 powołanej ustawy).

Decyzje o wpisie do wykazu czasopism oraz o przypisaniu czasopismom określonej liczby punktów powinny być szczegółowo uzasadniane i powinny podlegać kontroli sądowej, a możliwości składania skargi powinny mieć nie tylko jednostki naukowe, ale również zainteresowani wydawcy czasopism.

W sytuacji, w której wykaz utrzymywany byłby w sposób ciąły przez wyspecjalizowany podmiot, w sposób ściśle przewidziany przez prawo i kontrolowany pod tym kątem przez sąd, nie byłoby żadnych powodów, żeby kontynuować zasadę, że wykaz jest stosowany wstecz, do oceny publikacji, które ukazały się przed wydaniem wykazu.

39 II SA/Wa 1476/20, Lex nr 3124402.

40 Tak uznał WSA w Warszawie w powoływanym już postanowieniu z 4 grudnia 2019 r., II SAB/Wa 575/19, Lex nr 2778006.

41 T.jedn.: Dz. U. 2019, poz. 1183 ze zm. 


\section{METODOLOGIA TWORZENIA POLSKICH WYKAZÓW CZASOPISM NAUKOWYCH}

Metody tworzenia wszystkich dotychczasowych polskich wykazów czasopism naukowych łączą dwie prawidłowości:

1) tylko część wykazu zawierająca czasopisma indeksowane w wybranych przez prawodawcę bazach tworzona była w sposób bibliometryczny, na podstawie wskaźników cytowań;

2) punktacja czasopism ustalana była zgodnie z założeniem, że czasopisma, o których mowa w punkcie 1, sa znacznie wyższej jakości od pozostałych czasopism.

Wykazy z lat 2005-2010 były podzielone na dwie części - czasopisma uwzględniane w Journal Citation Report oraz pozostałe czasopisma. Przykładowo, w wykazie z 2008 r. czasopismom uwzględnionym w Journal Citation Report przypisano od 10 do 30 punktów (na podstawie wskaźników cytowań danego czasopisma w tymże rankingu). Pozostałym czasopismom przypisywano od 2 do 6 punktów. Przyjmowano zatem, że czasopisma nieindeksowane w Journal Citation Report w najlepszym wypadku moga uzyskać 60\% punktów najsłabszych czasopism indeksowanych w tym rankingu. W obecnie obowiązującym rozwiązaniu jest zasadniczo podobnie - lista baz uległa pewnemu rozszerzeniu (cztery bazy należące do Web of Science oraz baza Scopus), ale wciąż czasopismom nieujętym w tych bazach nie można przypisać więcej niż 35\% maksymalnej liczby punktów, a górna część skali (100, 140 lub 200 pkt) jest zarezerwowana wyłącznie dla najlepiej cytowanych czasopism indeksowanych w wybranych bazach. Pozostałym czasopismo przypisuje się 20 pkt, a zespół ekspertów może to zmienić o maksymalnie dwa poziomy, a więc na 40 lub 70 pkt.

Założenie, że tylko czasopisma indeksowane w określonych bazach moga uzyskać wysoką liczbę punktów, byłoby prawidłowe tylko w sytuacji, w której spełnione byłyby określone warunki faktyczne, w szczególności takie jak:

1) cytowanie prac naukowych odbywa się według takich samych reguł w każdej dyscyplinie naukowej;

2) ilość badaczy i prac publikowanych w poszczególnych dyscyplinach naukowych jest podobna;

3) bazy, na których opiera się ocena, w pełni (albo przynajmniej w takim samym stopniu) reprezentują wyniki badań naukowych z każdej dyscypliny naukowej.

W rzeczywistości żaden z tych warunków nie jest spełniony. Poszczególne dziedziny nauki (a niekiedy nawet dyscypliny w obrębie tej samej dziedziny) wykazują się istotną statystycznie specyfika w zakresie typów publikowanych prac (np. w naukach społecznych duża część dyskursu naukowego toczy się na łamach monografii naukowych), oznaczania autorstwa publikacji naukowych (widocznym tego skutkiem jest to, że w niektórych bazach można zawężać listę cytowań do określonego typu autorstwa) i cytowania wcześniejszych prac. Ilość badaczy i prac publikowanych w poszczególnych dyscyplinach naukowych jest bardzo zróżnicowana. Zarówno bazy należące do grupy Web of Sci- 
ence, jak i Scopus w bardzo różnym stopniu są reprezentatywne dla publikacji z poszczególnych dziedzin i dyscyplin nauki. Oparcie rankingu czasopism na tych właśnie bazach $\mathrm{z}$ góry dyskryminuje te dyscypliny naukowe, które są w mniejszej skali w nich reprezentowane. Tymczasem tak właśnie jest w przypadku nauk prawnych. Nie dysponujemy wynikami badań na temat tego, w jakim stopniu bazy Web of Science i Scopus sa reprezentatywne dla oceny publikacji polskich naukowców. Badania takie niedawno przeprowadzono w Norwegii. Porównano w nich norweskie publikacje naukowe z lat 20152016 w narodowej bazie publikacji naukowych z tymi samymi publikacjami w bazach Web of Science i Scopus ${ }^{42}$. Uzyskano następujace wyniki:

- baza Scopus obejmuje 72\% norweskich publikacji naukowych z lat 2015 i 2016 ;

- bazy Web of Science obejmuja 69\% norweskich publikacji naukowych z lat 2015 i 2016 ;

- w przypadku nauk medycznych baza Scopus obejmuje $89 \%$ tych publikacji, a bazy Web of Science - 87\%;

- w przypadku nauk przyrodniczych, ścisłych oraz technicznych baza Scopus obejmuje 85\% tych publikacji, a bazy Web of Science - 84\%;

- w przypadku nauk społecznych baza Scopus obejmuje 48\% tych publikacji, a bazy Web of Science - 40\%;

- w przypadku nauk humanistycznych baza Scopus obejmuje 27\% tych publikacji, a bazy Web of Science $-23 \%{ }^{43}$.

Już te dane pokazuja, że punktacja czasopism w wykazie, który obejmuje czasopisma ze wszystkich dziedzin nauki, nie może być uzależniona wyłącznie od danych z baz Web of Science i Scopus, gdyż bazy te w bardzo różnym stopniu reprezentują wyniki badań naukowych z poszczególnych dziedzin nauki.

Cytowane badania nie ograniczyły się jednak do wskazania różnic pomiędzy dziedzinami nauki, ale zeszły również na poziom poszczególnych dyscyplin naukowych. Prawo należy do nauk społecznych, a te ogólne wskaźniki reprezentatywności miały znacznie lepsze od nauk humanistycznych. Okazuje się jednak, że w obrębie nauk społecznych wskaźniki reprezentatywności omawianych baz dla poszczególnych dyscyplin są bardzo zróżnicowane. O ile nauki ekonomiczne miały wskaźniki na poziomie $72 \%$, socjologia i politologia - pomiędzy $40 \%$ a 55\%, o tyle dla nauk prawnych wskaźniki te były najniższe z wszystkich dyscyplin naukowych. Baza Scopus obejmuje 20\% wszystkich norweskich publikacji z zakresu nauk prawnych z lat 2015 i 2016, a bazy Web of Science - zaledwie 12\%. W przypadku polskich badań te współczynniki byłyby zapewne jeszcze niższe ${ }^{44}$. Należy bowiem wskazać, że dysproporcje w re-

${ }^{42}$ Aksnes, Sivertsen (2019): 1.

43 Aksnes, Sivertsen (2019): 1.

44 W bazie Scopus w kategorii „prawo” 8 lutego 2021 r. odnotowywano 596 publikacji z lat 2017-2019 afiliowanych przy uczelniach norweskich i 540 publikacji afiliowanych przy uczelniach polskich. Biorąc pod uwagę wielkość państw oraz ilość uczelni w obu państwach, należy ocenić, że znacznie mniejszy odsetek polskich publikacji z zakresu nauk prawnych jest zindeksowany w omawianej bazie niż publikacji norweskich. 
prezentatywności opisywanych baz występują nie tylko pomiędzy dyscyplinami naukowymi, ale również pomiędzy poszczególnymi państwami.

Omawiane dysproporcje w reprezentatywności baz Web of Science i Scopus w odniesieniu do poszczególnych dyscyplin naukowych mają podwójne znaczenie dla tworzenia rankingu czasopism naukowych:

1) w odniesieniu do czasopism ujętych w tych bazach dysproporcje te zaburzaja możliwość porównywania ze sobą wskaźników cytowań czasopism należących do różnych dyscyplin (ponieważ czasopisma należące do dyscyplin, których wyniki są w znacznym stopniu prezentowane w bazach, będa miały znacznie wyższe wskaźniki cytowań niż czasopisma należące do dyscyplin, których wyniki tylko w niewielkim stopniu są prezentowane w tych bazach),

2) w odniesieniu do czasopism nieujętych w tych bazach oparcie się wyłacznie na danych $\mathrm{z}$ tych baz uniemożliwia utworzenie rankingu, w którym byłyby uwzględnione zarówno czasopisma indeksowane, jak i nieindeksowane w tych bazach.

Rozwiązaniem pierwszego problemu (a także innych zasygnalizowanych powyżej problemów, które skutkują różnicami pomiędzy poszczególnymi dziedzinami i dyscyplinami naukowymi) byłoby przyjęcie, że w obrębie każdej dyscypliny naukowej stosuje się podobne proporcje pomiędzy grupami czasopism o określonej punktacji.

Drugi problem jest znacznie trudniejszy do rozwiązania. Należy jednak zauważyć, że przyjęte obecnie rozwiązanie (że czasopisma nieindeksowane w bazach Web of Science i Scopus nie są oceniane w sposób bibliometryczny i w efekcie nie mają szans na uzyskanie wysokiej liczby punktów) nie jest jedynym możliwym. Oceny bibliometryczne mogą być bowiem dokonywane nie tylko na podstawie baz Web of Science i Scopus. Uzupełniająco można bowiem korzystać z bazy Google Scholar, a także z baz dziedzinowych.

$\mathrm{Na}$ możliwość korzystania z bazy Google Scholar ${ }^{45}$ wskazuje coraz więcej badaczy z zakresu bibliometrii. Wszystkie dostępne wyniki badań pokazuja, że Google Scholar wykazuje znacznie wyższy stopień pokrycia (szczególnie w naukach społecznych i humanistycznych) niż bazy Web of Science i Scopus ${ }^{46}$, co znacząco wpływa na wskaźniki wynikające z analizy cytowań pomiędzy dziedzinami nauki. Jak łatwo przewidzieć, dokonywanie tych analiz na podstawie Google Scholar daje możliwość zmniejszenia dyskryminacji dziedzin nauki, które sa stosunkowo mniej reprezentowane w bazach Web of Science i Scopus ${ }^{47}$, oraz publikacji naukowych, które powstały w innych językach niż język angielski ${ }^{48}$. Sa to kwestie szczególnie istotne dla czasopism z zakresu nauk prawnych. Jednocześnie należy podkreślić, że nie ma prze-

45 Baza Google Scholar została udostępniona w 2004 r. Była zaprojektowana jako wyspecjalizowana wyszukiwarka internetowa, a nie - narzędzie do dokonywania ocen bibliometrycznych. W 2007 r. udostępniony został program Publish or Perish (autorka pomysłu na ten program jest A.W. Harzing); umożliwia on dokonywanie analiz cytowań na podstawie danych z Google Scholar zarówno dla poszczególnych publikacji, jak i dla autorów oraz czasopism.

46 Zob. podsumowanie dotychczasowych badań w Harzing, Alakangas (2016): 788.

47 Zob. np. Harzing, Alakangas (2016): 797.

48 Zob. Martín-Martín et al. (2018): 1160. 
szkód formalnych, żeby bazę Google Scholar włączyć do procesu tworzenia polskiego wykazu czasopism naukowych, gdyż powoływany już art. 267 ust. 2 lit. b w związku z art. 265 ust. 9 pkt 2 Prawa o szkolnictwie wyższym i nauce stanowi, że wykazy czasopism naukowych powinny obejmować czasopisma „ujęte w międzynarodowych bazach czasopism naukowych o największym zasięgu", a baza Google Scholar niewątpliwie jest taką bazą (nawet w większym stopniu niż bazy Web of Science i Scopus). Dzięki jej włączeniu cały wykaz byłby tworzony w sposób jednolity, bibliometryczny. Dzięki temu, że istnieją czasopisma indeksowane w bazach Web of Science/ Scopus, a jednocześnie w bazie Google Scholar, możliwe jest tworzenie kompleksowych zestawień bibliometrycznych, w których według tych samych kryteriów oceniane będą wszystkie czasopisma naukowe. Czasopisma indeksowane w bazach Web of Science/ Scopus i w bazie Google Scholar moga pełnić rolę czasopism referencyjnych dla czasopism, które są indeksowane tylko w tej ostatniej.

Niechęć do włączania bazy Google Scholar do procesu tworzenia polskiego wykazu czasopism naukowych wynika zapewne z tego, że powstaje ona w sposób zautomatyzowany i zawiera błędy typowe dla tego sposobu tworzenia bazy (np. kilkukrotne liczenie cytowań z tego samego artykułu udostępnionego w kilku repozytoriach naukowych, mylne przypisywanie cytowania ksiązki artykułowi recenzującemu tę książkę itp.). Występowanie takich błędów wymaga jednak tylko, żeby wyniki uzyskane w danej bazie poddawane były krytycznej ocenie eksperckiej, a dokonywanie takiej oceny jest przewidziane w procedurze określonej w rozporządzeniu z 2018 r.

Innym powodem oporu przed właczaniem bazy Google Scholar do procesu tworzenia wykazu czasopism naukowych może być obawa, że może zostać w każdej chwili zamknięta. W przeciwieństwie do baz Web of Science i Scopus, na korzystanie z bazy Google Scholar nie zawiera się umów, które gwarantowałyby, że będzie ona dostępna przez określony czas. Nie powinno to jednak powstrzymywać przed korzystaniem z niej, póki jest dostępna. Podmiot odpowiedzialny za nią powinien archiwizować wyniki jej przeszukiwań, żeby w przyszłości można je było odtworzyć, nawet jeśli sama baza przestanie być dostępna.

W celu weryfikacji, czy wykaz czasopism uwzględniający cytowania zaindeksowane przez bazę Google Scholar byłby podobny do wykazów z lat 2019 i 2021, przeprowadziłem analizę kilkunastu wybranych polskich czasopism prawniczych. Analiza dotyczyła artykułów opublikowanych w tych czasopismach w latach 2010-2019. Przyjęcie 10-letniego okresu dla analizy znacznie odbiega od standardowo stosowanego w bazach Web of Science i Scopus okresu 3 lat. Trzyletni cykl życia publikacji naukowej jest typowy dla nauk ścisłych i medycznych. W naukach prawnych znacznie częściej niż w naukach ścisłych i medycznych cytuje się prace starsze niż z ostatnich 3 lat $^{49}$. Z drugiej strony jeszcze dalej idące wydłużenie okresu branego pod uwage nie odpowiadałoby celowi analizy, jakim jest ocena aktualnego poziomu czasopism. Wykorzystane do analizy dane o cytowaniach zostały uzyska-

${ }^{49}$ Maru (1976): 247. 
ne z programu Publish or Perish ${ }^{50}$ w dniach 16-20 lutego 2021 r. za pomoca przeszukiwania zasobów Google Scholar. Dane o liczbie artykułów opublikowanych na łamach danego czasopisma były pozyskiwane z różnych dostępnych źródeł. Różnią się od danych w bazie Google Scholar, gdyż w przypadku wielu czasopism w Google Scholar zaindeksowane były jedynie artykuły, które zostały przez kogokolwiek zacytowane, a nie były zaindeksowane artykuły nigdy niecytowane. Zdarza się również, że w Google Scholar ten sam artykuł zaindeksowany jest kilkukrotnie w różnych wersjach językowych. Jako artykuł potraktowano każdy tekst autorski niepochodzacy od redakcji danego czasopisma.

Do próby wybrałem polskie czasopisma prawnicze, którym znacząco podniesiono punktację w wykazach z lutego 2021 r. oraz, dla porównania, dwa czasopisma o utrwalonej pozycji w środowisku polskiej nauki prawa: „Ruch Prawniczy, Ekonomiczny i Socjologiczny” oraz „Państwo i Prawo”. Obydwa te czasopisma w wykazach z lutego 2021 r. utrzymały punktację przypisana im w ramach wykazu z lipca 2019 r. „Ruch Prawniczy, Ekonomiczny i Socjologiczny” otrzymał wówczas 40 pkt (wszedł na listę jako beneficjent programu „Wsparcie dla czasopism naukowych” i zespół ekspertów podwyższył punktację o jeden poziom). „Państwo i Prawo” otrzymało wówczas 70 pkt (zostało dodane do wykazu na podstawie deklaracji o wystapieniu o wpis do bazy ERIH+ i zespół ekspertów podwyższył mu punktację o dwa poziomy).

Do czasopism prawniczych, którym znacząco podniesiono punktację w wykazach z lutego 2021 r., zaliczyłem te czasopisma prawnicze, którym w wykazach z lutego 2021 r. podwyższono punktację na 70 lub 100 pkt. Zaliczam do nich „Białostockie Studia Prawnicze”, „Biuletyn Stowarzyszenia Absolwentów i Przyjaciół Wydziału Prawa Katolickiego Uniwersytetu Lubelskiego”, „Kościół i Prawo”, „Kwartalnik Prawa Prywatnego”, „Nieruchomości@”, „Przegląd Konstytucyjny”, „Przegląd Prawa Konstytucyjnego”, „Przegląd Sądowy”, „Przegląd Sejmowy”, „Review of European and Comparative Law”, „Roczniki Nauk Prawnych”, „Studia Iuridica”, „Studia Iuridica Lublinensia”, „Studia Prawnicze KUL”, „Teka Komisji Prawniczej”1.

„Białostockie Studia Prawnicze” w wykazie z grudnia 2019 r. miały 20 pkt (gdyż były indeksowane w bazie ERIH+), a w wykazie z 18 lutego 2021 r. przypisano im 100 pkt. Na łamach tego czasopisma w latach 2010-2019 opublikowano łącznie 512 artykułów ${ }^{52}$, które zostały zacytowane w 162 publikacjach.

„Biuletyn Stowarzyszenia Absolwentów i Przyjaciół Wydziału Prawa Katolickiego Uniwersytetu Lubelskiego" nie był uwzględniony w wykazach z 2019 r. Jest indeksowany w bazie ERIH+. Został dodany do wykazu w lutym 2021 r., przy czym od razu przypisano mu 70 pkt. W czasopiśmie tym w latach

${ }^{50}$ Harzing's Publish or Perish, wersja 7.29.3156.7695.

51 W wykazach z lutego 2021 r. znalazło się nieco więcej czasopism przypisanych do dyscypliny nauki prawne, które uzyskały po 70 lub 100 pkt, ale w porównaniu pominąłem te, które nie ograniczają się do nauk prawnych.

${ }^{52} \mathrm{Na}$ podstawie strony czasopisma. Baza Google Scholar wykazywała mniejszą liczbę artykułów. 
2010-2019 opublikowano łącznie 172 artykuły ${ }^{53}$, które zostały zacytowane w 25 publikacjach.

Czasopismo „Kościół i Prawo” w wykazie z grudnia 2019 r. miało 20 pkt (gdyż było indeksowane w bazie ERIH+), a w wykazie z 18 lutego 2021 r. przypisano mu 70 pkt. Na łamach tego czasopisma w latach 2010-2019 opublikowano łącznie 239 artykułów ${ }^{54}$, które zostały zacytowane w 150 publikacjach.

„Kwartalnik Prawa Prywatnego” nie był uwzględniony w wykazie z grudnia 2019 r. Został zaaprobowany do bazy ERIH+ w marcu 2020 r. i na tej podstawie został dodany do wykazu z 2021 r., przy czym od razu przypisano mu 70 pkt. W latach 2010-2019 na łamach tego czasopisma opublikowano łącznie 291 artykułów ${ }^{55}$, które zostały zacytowane w 291 publikacjach.

Kwartalnik „Nieruchomości@” zaczął się ukazywać w 2019 r. i dlatego nie był uwzględniony w wykazie z grudnia 2019 r. Nie był widoczny 25 lutego 2021 r. w bazie ERIH+, nie był też beneficjentem programu WCN. Mimo to został dodany do wykazu z 2021 r., przy czym od razu przypisano mu 70 pkt. W roku 2019 na łamach tego czasopisma opublikowano 21 artykułów ${ }^{56}$, które zostały zacytowane w 2 publikacjach.

„Państwo i Prawo”, jak już wspomniałem, w wykazach z 2019 i 2021 r. ma po 70 pkt. Jest wpisane do bazy ERIH+. W latach 2010-2019 na łamach tego czasopisma opublikowano łącznie 1818 artykułów ${ }^{57}$, które zostały zacytowane w 2006 publikacjach.

„Przegląd Konstytucyjny” ukazuje się od 2017 r. i nie był uwzględniony w wykazie z grudnia 2019 r. Został zaaprobowany do bazy ERIH+ w marcu 2020 r. i na tej podstawie został dodany do wykazu z 2021 r., przy czym od razu przypisano mu 70 pkt. W latach 2017-2019 na łamach tego czasopisma opublikowano łącznie 98 artykułów ${ }^{58}$, które zostały zacytowane w 67 publikacjach.

„Przegląd Prawa Konstytucyjnego” w wykazie z grudnia 2019 r. miał 40 pkt (gdyż był indeksowany w bazie ERIH+ oraz był beneficjentem programu WCN), a w wykazie z 18 lutego 2021 r. przypisano mu 100 pkt. Na łamach tego czasopisma w latach 2010-2019 opublikowano łacznie 1003 artykuły ${ }^{59}$, które zostały zacytowane w 801 publikacjach.

${ }^{53} \mathrm{Na}$ podstawie strony czasopisma. Baza Google Scholar wykazywała mniejszą liczbę artykułów.

${ }^{54} \mathrm{Na}$ podstawie strony czasopisma. Baza Google Scholar wykazywała większą liczbę artykułów.

${ }^{55} \mathrm{Na}$ podstawie SIP Lex [dostęp: 25.02.2021]. Baza Google Scholar wykazywała mniejszą liczbę artykułów.

${ }^{56} \mathrm{Na}$ podstawie strony czasopisma [dostęp: 25.02.2021]. Baza Google Scholar wykazywała nieco mniejszą liczbę artykułów.

${ }^{57} \mathrm{Na}$ podstawie SIP Lex [dostęp: 25.02.2021]. Baza Google Scholar wykazywała znacznie mniejszą liczbę artykułów.

${ }_{58} \mathrm{Na}$ podstawie strony czasopisma [dostęp: 25.02.2021]. Baza Google Scholar wykazywała nieco mniejszą liczbę artykułów.

${ }^{59} \mathrm{Na}$ podstawie bazy CEJSH [dostęp: 25.02.2021]. Baza Google Scholar wykazywała mniejszą liczbę artykułów. 
„Przegląd Sądowy” w wykazie z grudnia 2019 r. miał 20 pkt (gdyż był indeksowany w bazie ERIH+), a w wykazie z 18 lutego 2021 r. przypisano mu 70 pkt. Na łamach tego czasopisma w latach 2010-2019 opublikowano łącznie 1122 artykuły $^{60}$, które zostały zacytowane w 494 publikacjach.

„Przegląd Sejmowy” w wykazie z grudnia 2019 r. miał 70 pkt (był beneficjentem programu WCN, a obecnie jest indeksowany w bazie Emerging Sources Citation Index należącej do grupy Web of Science), z kolei w wykazie z 18 lutego 2021 r. przypisano mu 100 pkt. Na łamach tego czasopisma w latach 2010-2019 opublikowano łącznie 1101 artykułów ${ }^{61}$, które zostały zacytowane w 1039 publikacjach.

Czasopismo „Review of European and Comparative Law” (wcześniej zatytułowane „Review of Comparative Law”) w wykazie z grudnia 2019 r. miało 40 pkt (było beneficjentem programu WCN, obecnie jest również indeksowane w bazie ERIH+), a w wykazie z 18 lutego 2021 r. przypisano mu 70 pkt. Na łamach tego czasopisma w latach 2010-2019 opublikowano łącznie 163 artykuły ${ }^{62}$, które zostały zacytowane w 19 publikacjach.

„Roczniki Nauk Prawnych” w wykazie z grudnia 2019 r. miały 40 pkt (były indeksowane w bazie ERIH+), a w wykazie z 18 lutego 2021 r. przypisano im 70 pkt. Na łamach tego czasopisma w latach 2010-2019 opublikowano łącznie 451 artykułów ${ }^{63}$, które zostały zacytowane w 248 publikacjach.

„Ruch Prawniczy, Ekonomiczny i Socjologiczny”, jak już wspomniałem, w wykazach z 2019 i 2021 r. otrzymał za każdym razem 40 pkt. Był beneficjentem programu WCN. W latach 2010-2019 na łamach tego czasopisma opublikowano łącznie 857 artykułów ${ }^{64}$, które zostały zacytowane w 1468 publikacjach.

Czasopismo „Studia Iuridica” w wykazie z grudnia 2019 r. miało 20 pkt (gdyż były indeksowane w bazie ERIH+), a w wykazie z 18 lutego 2021 r. przypisano mu 100 pkt. Na łamach tego czasopisma w latach 2010-2019 opublikowano łącznie 502 artykuły ${ }^{65}$, które zostały zacytowane w 214 publikacjach.

Czasopismo „Studia Iuridica Lublinensia” w wykazie z grudnia 2019 r. miało 40 pkt (było indeksowane w bazie ERIH+ oraz było beneficjentem programu WCN), z kolei w wykazie z 18 lutego 2021 r. przypisano mu 70 pkt. Na

${ }^{60} \mathrm{Na}$ podstawie SIP Lex [dostęp: 25.02.2021]. Baza Google Scholar wykazywała mniejsza liczbę artykułów.

${ }^{61} \mathrm{Na}$ podstawie SIP Lex [dostęp: 25.02.2021]. Baza Google Scholar wykazywała mniejsza liczbę artykułów.

${ }^{62}$ Liczba artykułów z lat 2015-2019 na podstawie SIP Lex [dostęp: 25.02.2021], do tej liczby dodano liczbę artykułów z lat 2010-2014 na podstawie strony czasopisma. Baza Google Scholar wykazywała mniejszą liczbę artykułów.

${ }^{63}$ Na podstawie bazy CEEOL [dostęp: 25.02.2021]. Baza Google Scholar wykazywała większą liczbę artykułów.

${ }^{64}$ Na podstawie SIP Lex [dostęp: 25.02.2021]. Baza Google Scholar wykazywała mniejszą liczbę artykułów.

${ }^{65}$ Liczba artykułów z lat 2010-2018 na podstawie SIP Lex [dostęp: 25.02.2021], do tej liczby dodano liczbę artykułów z 2019 r. Baza Google Scholar wykazywała nieco większą liczbę artykułów. 
łamach tego czasopisma w latach 2010-2019 opublikowano łącznie 628 artykułów ${ }^{66}$, które zostały zacytowane w 888 publikacjach.

Czasopismo „Studia Prawnicze KUL” w wykazie z grudnia 2019 r. miało 40 pkt (było indeksowane w bazie ERIH+ oraz było beneficjentem programu WCN), a w wykazie z 18 lutego 2021 r. przypisano mu 100 pkt. Na łamach tego czasopisma w latach 2010-2019 opublikowano łącznie 540 artykułów ${ }^{67}$, które zostały zacytowane w 81 publikacjach.

Czasopismo „TEKA Komisji Prawniczej” w wykazie z grudnia 2019 r. miało 40 pkt (było indeksowane w bazie ERIH+ oraz było beneficjentem programu WCN), a w wykazie z 18 lutego 2021 r. przypisano mu 100 pkt. Na łamach tego czasopisma w latach 2010-2019 opublikowano łącznie 236 artykułów ${ }^{68}$, które zostały zacytowane w 82 publikacjach.

Gdyby powyższe dane przedstawić w postaci rankingu, w którym o miejscu danego czasopisma decydowałbym współczynnik cytowań do liczby opublikowanych artykułów ${ }^{69}$, otrzymalibyśmy listę przedstawioną w tabeli 1.

Z powyższego zestawienia wynika, że wartości punktowe przypisane analizowanym czasopismom w dotychczasowych wykazach w większości przypadków nie znajdują uzasadnienia w danych dotyczących cytowań tych czasopism. Gdyby cały wykaz był sporządzany zgodnie z metodologia analogiczna do metodologii tworzenia wykazu dla czasopism indeksowanych w bazach Web of Science czy Scopus (a więc na podstawie analizy wpływu danego czasopisma, postrzeganego przez pryzmat liczby cytowań artykułów z tego czasopisma w porównaniu z liczbą opublikowanych w nim artykułów), to większości $\mathrm{z}$ analizowanych czasopism zostałyby przypisane liczby punktów odmienne od tych, które znalazły się w wykazach z lutego 2021 r. Punktacja „Ruchu Prawniczego, Ekonomicznego i Socjologicznego" nie odzwierciedla jego faktycznej pozycji w polskiej nauce. Na tle tych czasopism, które w wykazie maja więcej punktów, jest on zdecydowanie niedoszacowany. Punktację adekwatną do uzyskanych cytowań mają czasopisma „Studia Iuridica Lublinensia”, „Państwo i Prawo” oraz „Kwartalnik Prawa Prywatnego”. Punktacja pozostałych czasopism jest zawyżona, niekiedy znacznie. To, jaka punktacja byłaby właściwsza dla tych czasopism, wymagałoby przeprowadzenia dalszych analiz obejmujacych pozostałe czasopisma prawnicze, które obecnie w wykazie maja niższą punktację.

${ }^{66} \mathrm{Na}$ podstawie SIP Lex [dostęp: 25.02.2021]. Baza Google Scholar wykazywała znacznie większą liczbę artykułów.

${ }^{67} \mathrm{Na}$ podstawie SIP Lex [dostęp: 25.02.2021]. Baza Google Scholar wykazywała mniejszą liczbę artykułów.

68 Obliczenia własne na podstawie strony czasopisma [dostęp: 25.02.2021]. Baza Google Scholar wykazywała znacznie mniejszą liczbę artykułów.

69 Tak działa np. CiteScore - wskaźnik bibliometryczny stanowiący miarę cytowalności czasopism w bazie Scopus. Różnica polega na tym, że CiteScore bierze pod uwagę artykuły $\mathrm{z}$ trzech lat. 


\section{Tabela 1}

Zestawienie liczby artykułów publikowanych w wybranych czasopismach w latach 2010-2019 z liczbą cytowań tych artykułów

\begin{tabular}{|c|c|c|c|}
\hline Czasopismo & $\begin{array}{c}\text { Liczba artykułów } \\
\text { opublikowanych } \\
\text { w latach } \\
2010-2019\end{array}$ & $\begin{array}{c}\text { Liczba cytowań } \\
\text { artykułów } \\
\text { opublikowanych } \\
\text { w latach } \\
\text { 2010-2019 }\end{array}$ & $\begin{array}{c}\text { Współczynnik } \\
\text { cytowań do liczby } \\
\text { artykułów }\end{array}$ \\
\hline $\begin{array}{l}\text { Ruch Prawniczy, Ekono- } \\
\text { miczny i Socjologiczny }\end{array}$ & 857 & 1468 & 1,7 \\
\hline $\begin{array}{l}\text { Studia Iuridica Lublinen- } \\
\text { sia }\end{array}$ & 628 & 888 & 1,4 \\
\hline Państwo i Prawo & 1818 & 2006 & 1,1 \\
\hline $\begin{array}{l}\text { Kwartalnik Prawa Pry- } \\
\text { watnego }\end{array}$ & 291 & 291 & 1,0 \\
\hline Przegląd Sejmowy & 1101 & 1039 & 0,9 \\
\hline $\begin{array}{l}\text { Przegląd Prawa Konstytu- } \\
\text { cyjnego }\end{array}$ & 1003 & 801 & 0,8 \\
\hline Przegląd Konstytucyjny & 98 & 67 & 0,7 \\
\hline Kościół i Prawo & 239 & 150 & 0,6 \\
\hline Roczniki Nauk Prawnych & 451 & 248 & 0,5 \\
\hline Przegląd Sądowy & 1122 & 494 & 0,4 \\
\hline Studia Iuridica & 502 & 214 & 0,4 \\
\hline Teka Komisji Prawniczej & 236 & 82 & 0,3 \\
\hline $\begin{array}{l}\text { Białostockie Studia Praw- } \\
\text { nicze }\end{array}$ & 512 & 162 & 0,3 \\
\hline Studia Prawnicze KUL & 540 & 81 & 0,2 \\
\hline $\begin{array}{l}\text { Review of European and } \\
\text { Comparative Law }\end{array}$ & 163 & 19 & 0,1 \\
\hline $\begin{array}{l}\text { Biuletyn Stowarzyszenia } \\
\text { Absolwentów i Przyjaciół } \\
\text { Wydziału Prawa Kato- } \\
\text { lickiego Uniwersytetu } \\
\text { Lubelskiego }\end{array}$ & 172 & 25 & 0,1 \\
\hline Nieruchomości@ & 21 & 2 & 0,1 \\
\hline
\end{tabular}

Źródło: opracowanie własne.

Jednocześnie warto powtórzyć, że dzięki temu, że czasopisma indeksowane w bazach Web of Science i/ lub w bazie Scopus sa jednocześnie indeksowane w bazie Google Scholar, dysponujemy danymi, które umożliwiają tworzenie wykazu czasopism w sposób jednolity dla wszystkich czasopism. Nie ma potrzeby przyjmowania domniemania, że czasopisma nieindeksowane w bazach Web of Science czy Scopus są znacznie niższej jakości. Dzięki danym z Google 
Scholar możliwe jest bowiem miarodajne, rzetelne porównanie takich czasopism z czasopismami indeksowanymi w bazach Web of Science czy Scopus.

Największym problemem przy bibliometrycznej ocenie czasopism, które nie sa indeksowane w bazach Web of Science czy Scopus, jest ustalanie liczby artykułów opublikowanych w danym czasopiśmie. Baza ERIH+ nie zawiera takich informacji, dlatego obowiązujące rozporządzenie powinno zawierać wymaganie, by czasopismo starające się o wpis do wykazu czasopism, niezależnie od wpisania się do bazy ERIH+, wskazywało bazę referencyjna, na podstawie której ustalana będzie jego zawartość. W przypadku stwierdzenia, że wskazana przez wydawnictwo baza nie reprezentuje pełnej zawartości danego czasopisma z ostatnich 10 lat, nie powinno być ono poddawane analizie bibliometrycznej i otrzymywałoby wyłącznie minimalną liczbę punktów.

\section{OCENY PARAMETRYCZNE POLSKICH CZASOPISM PRAWNICZYCH - PROBLEMY CZASOPISM INTERDYSCYPLINARNYCH}

Specyficzne problemy pojawiają się w przypadku czasopism, które publikują artykuły należące do różnych dyscyplin naukowych. Problemy te ujawniają się zarówno na etapie ocen bibliometrycznych (gdyż - jak już wspomniałem - poszczególne dyscypliny naukowe wykazują znaczące zróżnicowanie we wskaźnikach cytowań), jak i na etapie oceny eksperckiej (gdyż czasopismo cieszące się poważnym prestiżem $\mathrm{w}$ danej dyscyplinie może być znacznie niżej oceniane przez ekspertów z innej dyscypliny).

Jak już była o tym mowa, art. 265 ust. 10 Prawa o szkolnictwie wyższym stanowi, że „czasopismom i materiałom z konferencji przypisuje się dyscypliny naukowe". Ani ustawa, ani rozporządzenie z $2018 \mathrm{r}$. nie precyzuja procedury przypisywania dyscyplin do czasopism, nie przewidują również możliwości odwołania się od decyzji w tej sprawie. „Ruch Prawniczy, Ekonomiczny i Socjologiczny” został prawidłowo przypisany do dyscyplin „ekonomia i finanse”, „nauki prawne” i „nauki socjologiczne”. Jednakże w wielu przypadkach dyscypliny przypisane czasopismom nie odpowiadały ich profilowi. W takich przypadkach zdarzały się znaczące różnice w ocenie eksperckiej dokonywanej przez zespoły z poszczególnych dyscyplin. Przykładem może być czasopismo „Polish Yearbook of International Law”: mimo że jest to czasopismo wyłacznie prawnicze, zostało przypisane nie tylko do „nauk prawnych”, ale również do „nauk o bezpieczeństwie” oraz do „prawa kanonicznego”70. W efekcie zespół reprezentujący nauki prawne przyznał temu czasopismu najwyższą możliwa liczbę punktów (czyli 70), ale zespoły reprezentujące dwie pozostałe dyscypliny przyznały jedynie po 20 pkt. W takiej sytuacji, zgodnie z $§ 14$ ust. 3 rozpo-

${ }^{70}$ Inne przykłady takich błędów to np. czasopismo „Religion \& Human Rights” przypisane do „historii”, „nauk o kulturze i religii” oraz „prawa kanonicznego” (a do nauk prawnych nie), albo „Australian Feminist Law Journal” przypisane wyłącznie do „nauk o kulturze i religii”. 
rządzenia z 2018 r., czasopismu przypisano 40 pkt jako punktację zbliżoną do średniej arytmetycznej z punktacji uzyskanej w poszczególnych dyscyplinach. W tym przypadku znaczący wpływ na ostateczną punktację miały więc dyscypliny, dla których omawiane czasopismo miało marginalne znaczenie. Nie był to odosobniony przypadek, dlatego w nowelizacji z listopada $2019 \mathrm{r}$. zmieniono $\S 14$ rozporządzenia z 2018 r. w ten sposób, że w przypadku gdy różnica wartości punktów przypisanych w ramach poszczególnych dyscyplin naukowych wynosi co najmniej dwa progi punktowe, Komisja Ewaluacji Nauki dokonuje dodatkowej oceny tego czasopisma i na tej podstawie przypisuje mu punkty. Ponieważ jednak oceny eksperckie nie zostały już później przeprowadzone, rozwiązanie to nie zostało zastosowane i błędy popełnione w zakresie przypisywania dyscyplin naukowych przy ocenie eksperckiej przeprowadzonej w 2019 r. nie zostały do tej pory poprawione. W procedurze przypisywania dyscyplin do czasopism powinno się też uwzględniać stanowisko redakcji danego czasopisma.

\section{PODSUMOWANIE}

Dotychczasowe zasady wydawania urzędowego wykazu czasopism naukowych w Polsce miały wiele wad. W szczególności za wadliwe należy wskazać, że wykazy działały i wciąż działają retroaktywnie. Nie sprawdziło się powierzenie wydawania wykazu ministerstwu, ostatnimi czasy doszło bowiem do wielu nadużyć przy wydawaniu tego wykazu. De lege ferenda należy więc zgłosić następujące postulaty:

1) wykaz czasopism naukowych nie powinien być sporządzany przez ministerstwo, lecz przez niezależną agencję naukowa;

2) decyzje o wpisie do wykazu i nadaniu punktów powinny być szczegółowo uzasadniane i powinny podlegać kontroli sądowej (przy czym redakcjom czasopism powinny przysługiwać uprawnienia strony postępowania);

3) wykaz powinien wywoływać wyłącznie skutki na przyszłość.

$\mathrm{W}$ odniesieniu do metodologii tworzenia wykazu powyższe uwagi pozwalają na sformułowanie kolejnych postulatów:

4) wykaz powinien w całości być opracowywany zgodnie $z$ ujednolicona metodologia, w której zasadniczym elementem oceny jest analiza cytowań;

5) procedura przypisywania czasopismom dyscyplin naukowych powinna być bardziej transparentna i powinna uwzględniać stanowiska redakcji zainteresowanych czasopism.

Aksnes, D.W., Sivertsen, G. (2019). A criteria-based assessment of the coverage of Scopus and Web of Science. Journal of Data and Information Science 4(1): 1-21.

Harzing, AW., Alakangas, S. (2016). Google Scholar, Scopus and the Web of Science: a longitudinal and cross-disciplinary comparison. Scientometrics 106: 788-804.

Martín-Martín, A., Orduna-Malea, E., Thelwall, M. Delgado López-Cózar, E. (2018). Google Scholar, Web of Science, and Scopus: a systematic comparison of citations in 252 subject categories. Journal of Informetrics 12(4): 1160-1178. 
Maru, O. (1976). Measuring the impact of legal periodicals. American Bar Foundation Research Journal 1: 227-249.

Pietrzykowski, T. (2004). Wsteczne działanie prawa i jego zakaz. Kraków.

Wierczyński, G. (2020). Problemy oceny parametrycznej polskich czasopism naukowych z dziedziny nauk prawnych. Państwo i Prawo 75(9): 3-22.

\section{POLISH LISTS OF SCIENTIFIC JOURNALS - A SUMMARY OF EXPERIENCES TO DATE FROM THE PERSPECTIVE OF LAW JOURNALS}

Sum mary

The first part of the article discusses the rules regulating the creation of the official list of scientific journals in Poland. The author concludes that these rules have many flaws. Among the de lege ferenda conclusions, the author mentions: (i) the list cannot be applied retroactively, it should only have effects for the future; (ii) decisions concerning inclusion on the list and awarding points should be justified, and these justifications should be publicly available; (iii) decisions concerning inclusion on the list of scientific journals and the awarding of points to scientific journals should be subject to judicial control; (iv) the list of scientific journals should not be prepared by the ministry, but by an independent scientific agency; (v) the list should be fully developed on the basis of a unified, transparent methodology, in which the essential element of the evaluation is the analysis of journal citations. The second part of the article discusses the scientific databases used to create rankings of scientific journals. The author points out that in relation to European legal journals, the Web of Science and Scopus databases include content that is too limited to be properly used for this purpose. The author suggests taking into account the citations from the Google Scholar database to evaluate European scientific legal journals.

Keywords: scientific legal journals; science evaluation 
